changes are $1 \cdot 6$ per cent and $3 \cdot 9$ per cent respectively. The Osira lamps run at the standard pressure of 230 volts. A mile of the Watford Road, Wembley, is lit by them. The sudden change from ordinary light. ing to Osira lighting is rather a shock when driving along the road, but doubtless the colour deficiency will soon be improved.

\section{Schemes for National Re-Equipment}

In the opening passages of his presidential address to the Institution of Mechanical Engineers, delivered on October 27, Mr. A. E. L. Chorlton, M.P., said that the old laissez faire policy of the Victorian era belongs to an age now gone by and that to-day more coordinated direction and control of public services is necessary in Great Britain if we are to increase the general facilities for industry and the amenities of social life. The various public services of the country, light, heat, power and water supply were all developed separately with but little inter-connexion, but it is now agreed that if they had been properly interrelated, a much more efficient system would have resulted at a far smaller first cost. Taking water supply as an example, Mr. Chorlton went on to show how by suitable trunk pipe lines the water from areas with heavy rainfalls could be used to supplement the present supplies. It is imperative that the whole of the available water supplies of the country should be investigated, and a scheme developed somewhat on the lines of the electricity scheme. There are also many arguments for the interconnexion of existing gas undertakings by a 'gas grid', among which is that the development in many areas of coke-oven installations makes available large quantities of gas. Mr. Chorlton was able to give emphasis to his views by reference to long-distance transmission schemes for water and for gas abroad, and incidentally mentioned that Chicago obtains its gas supply from the oil fields of Texas a thousand miles away. Speaking of the 'electric grid' in Great Britain, Mr. Chorlton said that it is the largest thing of its kind in the world and in the supply and dis. tribution of electricity we are now in the forefront. There are many other schemes of national re-equipment which need investigation and in which mechanical engineers can play an important part. With reference to Mr. Chorlton's remarks on water supply in England, we may direct attention to his article on this subject published in Engineering of October 13 and 27.

\section{Identification of Coronal Lines}

A Message from its New York correspondent published by the Times of October 27 states that Drs. D. H. Menzel and J. C. Boyce have identified some of the well-known coronal lines. These lines, which occur in the spectrum of the solar corona, have remained unidentified for several decades, and were at one time supposed to indicate the presence in the corona of a new element, which was ealled coronium. This hypothesis had, of course, the precedent of the discovery of the element helium by the same method to support it, but of recent years it has not been usual to suppose that the actual element coronium exists. A few years ago, Bowen identified the nebulium lines. These lines, which appeared as very strong emission lines in the spectrum of nebulæ, were shown to be 'forbidden' lines in the iron spectrum. They are lines which do not appear in ordinary circumstances, but in the peculiar conditions of low density which obtain in nebulæ, the atom remains undisturbed in an excited state for a relatively long time, and has an opportunity to make the 'forbidden' transition. It became natural to suppose that the 'coronium' lines are also forbidden lines in a spectrum, the corona being at a very low pressure. Despite an exhaustive search for the required frequency intervals in known spectra, nothing had been found until recently. According to present announcement, Menzel and Boyce have now found the required intervals among the terms in the oxygen spectrum. It will be recalled that these coronal lines have been detected in the spectrum of the recent nova in Ophiuchus.

\section{Recent Acquisitions at the British Museum (Natural History)}

The Department of Zoology of the Museum has received some valuable specimens as the result of a cruise made by Mr. F. C. Fraser, of the Department, who, on the invitation of Col. E. T. Peel, accompanied the latter in his yacht to the north of Scotland, the Shetland Islands, and the Faröe during July. Mr. Fraser was able to make many observations on living dolphins and porpoises, and to secure excellent photographs, of which enlargements are now being prepared for exhibition in the New Whale Hall. A number of young birds and eggs were collected on the Faröe and the Shetland Islands, in particular a young specimen of the Arctic skua. A collection of some 8,500 insects, chiefly butterflies and moths, collected in Malaya by the late A. R. Sanderson, has been purchased for the Department of Entomology. The collection contains many specimens of value to the Museum particularly in connexion with the study of the geographical distribution of insects. A series of plant fructifications from Triassic rocks of South Africa, recently described by Dr. Hamshaw Thomas, and regarded as being Mesozoic representatives of the typically upper Palæozoic group of Pteridosperms, also a number of specimens of fungus-gnats and of small flowers in Baltic amber, have been purchased for the Department of Geology. The series of books on precious stones in the library of the Mineral Department has been added to by a valuable donation from Mr. Edward Heron-Allen of twelve volumes from his private library. The most interesting of these is an early edition, printed in Freiburg in 1531, of "De lapidibus pretiosis enchiridion", written in Latin verse by Marbode (10361123), Bishop of Rennes.

THE Department of Botany has had bequeathed to it the herbarium of the late C. C. Lacaita. Mr. Lacaita was well known for his wide interests and had a very considerable reputation as a European botanist. A few years ago he presented his mono- 
cotyledons and Sikkim plants to the Department. The present collection is estimated at 40,000 sheets, in excellent condition and order. Its chief value is in Mr. Lacaita's own gatherings from various parts of Europe but particularly from Italy and Spainareas not over-well represented in the herbarium. There is further abundant material of those genera in which he had specialised, such as Helianthemum, Echium, Onosma, Pulmaria and Cirsium. The collection also contains a number of exsiccata, some of which were not previously represented in the Museum collections. Mr. A. H. G. Alston, assistant keeper in the Department, visited southern Albania in the summer in company with Mr. N. Y. Sandwith, of the Kew Herbarium. They explored many districts from which no previous collections are known. About a thousand different plants were collected. Although these have not yet been worked through, they evidently include many rare and little-known species. The collection, in conjunction with that made in Macedonia last year, will give a good deal of information about plant distribution in the Balkan Peninsula. Mr. G. Tandy, assistant keeper in the Department, has again visited the Tortugas, Florida, and has collected about 650 numbers. These contain a very interesting series from experiments on growthforms of species of Caulerpa, which will yield valuable taxonomic results. Mir. J. Gossweiler has presented a further 433 specimens of Angola flowering plants.

\section{Friends of the National Libraries}

THE Friends of the National Libraries, a body formed in 1931 to promote and assist in the acquisition by the national libraries of important works and manuscripts, has issued its second annual report, covering the year ending March 31, 1933 (Friends of the National Libraries, c/o British Museum, W.C.1). It is obvious that the main task of such a society must be to fill the gaps existing in the great collections of the British Museum, the Bodleian, and the other national libraries of Great Britain, and it is therefore all the more gratifying to find from the present report that the interests of the smaller and the special libraries are not being overlooked, and that many of the works secured during the year have gone to them. A notable example is the acquisition by the Royal Entomological Society of the first nine numbers of its own early Journal of the Proceedings of the Entomological Society of London, 1840-1846. Only ten numbers of this journal were issued (the Proceedings were incorporated with the Transactions from 1847 until 1926), and though copies were widely distributed at the time, they seemed to have become exceedingly rare and have for long been included in the desiderata of the Society's library.

Among other gifts of the Friends of the National Libraries, we find that four Linnæus items, including a unique copy of the fourth edition of Rousseau's "Letters on the Elements of Botany", 1794, have gone to the Natural History Museum, whilst the Science Library has benefited to the extent of more than a hundred volumes on navigation and kindred subjects. The latter formed part of a collection of books placed by the Corporation of Trinity House at the disposal of the Friends of the National Libraries for distribution, and show the Society in its secondary rôlo-as a clearing-house for unwanted and duplicate books. This is a service that should be widely known and utilised, for it provides the only means whereby works of mainly local or other special interest can find a permanent home in the libraries most fitted to receive them. The excellent record of work shown in this report deserves to be copied, and it may be suggested that 'friends of the national museums' should similarly organise themselves to help the Science Museum and others to add to their collections.

\section{Chemical Engineering, Past and Present}

Prof. G. T. Morgan, director of Chemical Research under the Department of Scientific and Industrial Research, delivered a lecture before the Institution of Chemical Engineers on October 27 entitled, "Engineering in the Service of Chemical Research". Prof. Morgan is one of the exponents of high pressure chemistry, in which strong steel containers or autoclaves replace the glass test-tubes of the chemist. He described his successes at the Chemical Research Laboratory with pressures of 200 atmospheres at $450^{\circ} \mathrm{C}$. in inducing methyl alcohol and carbon monoxide to combine in the synthetic production of acetic acid. Apparatus has now been devised by which experiments can be carried out on pressures of 3,000 atmospheres, that is, about 20 tons per sq. in. The pressure-resisting parts for this plant are made from Sheffield nickel chromium molybdenum heat-treated steel. The plant is enclosed within steel screens so arranged that the various controls are operated from outside this protection. At the other extreme, constituents of coal tars difficult of separation are being obtained at the Laboratory by distillation of the tar at very low pressure (of the order of a thousand millionth of an atmosphere) in a plant in which the cold condensation surface is placed so near the substance being distilled that its molecules escape direct to the condensing surface without contamination.

Prof. Morgan demonstrated the efficiency of a new wetting agent for mercerising cotton, developed at the Laboratory from coal-tar products, which is now being marketed under the name of Shirlacrol. He also described a new ether extracting plant, developed at the Laboratory, by which a Yorkshire firm is now successfully manufacturing resorcinol, a 'fine' chemical of considerable industrial importance, supplies of which have hitherto been entirely imported from abroad. All industrial applications of chemical science, engineering and chemistry are mutually indispensable and, so far as Great Britain is concerned, the advantages of such co-operation are more generally recognised to-day than they formerly were, but there is room for much improvement. Opportunities are boundless but without a closer collaboration between chemistry and engineering, we must certainly drift into the position of a 